stone being, at the great depths where they occur, reduced to a minimum, and yet even at the greatest depths they are found associated with Ophiurans, which are by no means wanting in lime. Among the Euspatangia, Spatangus purpureus occurred in the tropics at a depth of 400 fathoms, and Echinocardium australe was dredged at the great depth of 2,675 fathoms. In Australia it is a littoral zone species. Among the Brissina two species of Hemiaster were obtained allied to $H$. prunella, a new species of Rhinobrissus, and two new ones of Schizaster. No better idea can be given of the value of this extraordinary collection than by stating that there are described in this list no less than forty-four new species. At the time of the publication of Agassiz's "Revision of the Echini," there were scarcely over two hundred species of Echini known, and since that time less than fifty species have been added to the list. In the specific diagnosis of the species only the principal localities are given; the full details are reserved for the full report, which we believe is in good progress, many of the requisite illustrations being already engraved.

Atlantic Stalk-Eyed CRUstaceans.-Mr. S. J Smith, of Yale College, publishes, in the Transactions of the Connecticut Academy of Arts and Sciences (vol. v* part I), an account of the stalk-eyed crustaceans of the Atlantic Coast of North America. This account forms part of the report in preparation for the United States Commissioner of Fisheries. It embodies the study of the extensive collections made during the past fourteen years by Prof. Verrill and himself. In the present paper only the species inhabiting the coast between Cape Cod and Northern Labraclor are given, and although the paper has special reference to the geographical distribution of the species, considerable matter is introduced in regard to specific variation and specific characters, and under some of the species, to the synonymy, especially where it seemed necessary to the proper understanding of the geographical distribution, or to show the propriety of the nomenclature adopted, or where the species is not well known. The total number of species recorded is 73 , of which 45 are Decapods, I I Schizopods, and I7 Cumacex, one-half of which are also to be found in Europe, the author concluding that there is not only a close relationship between the marine fauna of Greenland and that of Northern Europe, but a similar close one between that of Greenland and of the coasts of the continent of North America.

LAND-SHELLS OF CALIFORNIAN AND MEXICAN IsLANDS. - In a short paper in Proc. Acad. Nat. Sci, of Philadelphia for 1879 (p. I6), Mr. W. G. Binney gives an important contribution to the geographical distribution of land-shells. The Mexican island of Guadelupe, 220 miles from San Diego, off the west coast of Lower California, has been visited by Dr. E. Palmer, and he found numerous fragments of snail-shells which had been devoured by a species of mouse, the only land mammal on the island. These appeared to belong to Arionta rowelli (Newcomb), found in Lower California. $A$. facto occurred, a variety with open umbilicus, like that found fossil on San Nicolas Island, California. Living specimens of Binneya notabitis were brought from Guadelupe, found also on the Californian island of Santa Barbara; it is very nearly allied to if not synonymous with the Mexican genus Xanthonyx. Thus it is supposed to have been first distributed from Mexico, then to Guadelupe, thence to Santa Barbara.

NEW GenUs OF Fishes approximating to THE MACKEREL. - In the San Francisco market a fish is often exposed for sale, having a long body, with more than seven finlets behind dorsal and anal fins, the body having long narrow scales on region behind the eye, on each side of the dorsal outline, and on base of tail ; the rest of the body is bare of scales. It has no corselet, and no teeth on vomer or palatines. There are fifteen dorsal spines, very fragile and slender. The ventral fins are very small, the colour is dark steel blue above, silvery below; and there are no streaks. The length of a specimen described by Mr. Lockington (Proc. Acad. Nat. Sci. Philadelphia, 1879, p. 136) was 21 inches to end of middle rays of caudal, length of head $4 \frac{1}{4}$ inches, greatest depth of body $4 \frac{1}{8}$ inches, length of pectoral fins $2 \frac{5}{8}$ inches, ventrals I inch.

HAIR-WORMS. - Curious knotted masses of hair-worms (Gorduis) are sometimes found in gutters after rain. Prof. Leidy disentangled one such mass last winter, containing fifty-two males and seven females; the former were from 8 to 25 centimetres long, and from one-balf to two-thirds of a millimetre in thickness; the latter from I4 to about 20 centimetres long and I millimetre thick. These worms are very lively; and when disentangled soon become again aggregated with the heads external and divergent.

Prof. MARSH, when examining recently the Rocky Mountain deposits known as the Atlantosaurus Beds, was rewarded by the discovery of the lower jaw of a mammal, a diminutive marsupial (somewhat smaller than a weasel), differing widely from any living type. The remarkable feature in the jaw is the series of premolar and molar teeth. The nearest affinities of this mammal are with the genus Stylodon, of Owen, from the Purbeck beds of England. Prof. Marsh designates the new genus Stylacodon, and the species represented $S$. gracilis.

\section{GEOGRAPHICAL NOTES}

AT the meetings of the International Geodetic Association at Geneva the representatives of the various countries present reported on the works executed by their governments. We are pleased to learn of a resolution of the French Ministry to proceed to a new levelling of precision of the first order on a length of 37,000 kilometres; a levelling of the second order will follow on a length of 800,000 kilometres. The operations to connect Spain and Algeria, to which we have referred were also described. The next meeting will be held at Munich in the autumn of 1880 .

A TELEGRAM from Samarkand to the Russian papers, informs us that the expedition for the tracing of a railway from Karaturghel to Tashkend and Samarkand has finished its explorations. It has explored the banks of the Syr-daria in the neighbourhoods of Kara-Uzyak, the coal-mines at Khojent, and the moving sands of Fergana, as well as a part of the Surkhan river and the roads from Samarkand through Djam-Karshee and Kitab-Shaar to the Iron Gate, and thence to the ruins of Termez on the Amu-daria. Throughout its route the expedition has made astronomical, meteorological, geological, botanical, and zoological researches; now it is engaged in a hydrographical description of the Amil-daria and of its delta.

THE Russian Government are actively pursuing the exploration of the great rivers of Russia in Europe. Thus, during the last three years the Volga was surveyed on a length of 775 miles; a thorough levelling is completed on 300 miles, and no less than 91,720 soundings give the necessary data for preparing a detailed map of the river. The Chussovaya river, one of the upper branches of the Kama river, has been explored on 270 miles, and the Byelaya, the other branch, on 160 miles. The Vyatka river is thoroughly surveyed and levelled. The description of the Vistula is quite completed. Extensive surveys and levellings were made on the river systems of the Dneiper and Bug, as well as on the Don, which is surveyed on a length of 560 miles. New surveys were undertaken last year on the Northern Drina and Sukhona, as well as in the basins of the Obi and Yenissei. Several stations were established for 
observations on the changes of levels of rivers, as well as for meteorological observations and for weather-warnings.

THE official Report on the Forests in the South and West of the Island of Cyprus, by Mr. A. E. Wild, of the Indian Forest Department, goes far to explain the unhealthy climatic conditions now existing in the island, and of which so much was recently said. In the region named the forests are now mostly confined to the chain of hills running east and west, and even there the more dense and better growth is confined to the more inaccessible spots of the higher ranges. Round the villages and in suitable localities for transport the forest is already so thinned as to be unworthy of the name. This unfortunate state of things, which has had a serious effect on the climate, has been brought about by the most reckless improvidence in the felling of trees, aided by fires and the ruinous mode of extracting resin. Mr. Wild appears to be of opinion that by a careful system of forest preservation, which need not involve us in a large expenditure of money, the damage caused under the Lusignan and Turkish rule, may be to a material extent repaired in the course of fifty or sixty years.

M. E. F. BERLIOUX, Professor of Geography at Lyons, has just issued a second edition, reviser, and enlarged, of his brochure, entitled "Les Anciennes Explorations et les Futures Decouvertes de l'Afrique Centrale," which is illustrated with a curious map of the northern portion of the continent.

A PARTY of forty-seven persons, amongst whom there are twelve married couples, and fourteen children, sailed last week from Bergen (Norway), with the intention of colonising the Aldabra Islands in the Indian Ocean (in about $9^{\circ}$ lat. S. and $46^{\circ}$ long. E.). The idea resulting in this undertaking was first conceived by two Norwegians, who had repeatedly visited Madagascar, where they had learnt that the Aldabra Islands are uninhabited at present, and excellently adapted for colonisation.

MUCH attention is just now being attracted in Queensland to the proposed scheme for a Transcontinental railway to Port Darwin on the northern coast, of the suggested route for which a flying survey has recently been made by Mr. Faveuc and a party who started from Blackall, in Queensland. The present idea is to commence the line at Roma on the existing system, whence it would be taken by way of Blackall to the South Australian frontier, a distance of 750 miles. From that point it would still follow a north-westerly direction to Port Darwin.

A MEMBER of the Japanese mission now at the capital of Corea writes to the Osaka Nippo that the new ports, which it is proposed to open in that country, are Jin-sen, in Kei-ki-dō, and Gen-san, in Kan-kiyo-dō, the former of which is only eight $r i$ distant from the capital. A Japanese surveying officer has also been engaged in making investigations at the port of Dai-on, in Kei-ki-dō, about eighteen rifrom the capital, along the road to which there are many royal tombs. Partly on this account, and also because the road is considered a very important one, the Coreans for some time obstinately refused to permit the surveying officer to travel over it; eventually, however, they gave way. Great benefit, it is thought, would accrue to commerce if this overland route were opened. The Corean capital numbers among its residents many nobles and wealthy men, and several of the latter, who hold progressive ideas, are said to have ordered European articles at the open port of Fusan in the south. When the port of Jin-sen comes to be opened, it is believed that foreign merchandise will be in great demand.

OFFICIAL statistics respecting the population of Netherlands India at the end of 1876 have lately been issued, from which it appears that exclusive of the army, there were then in Java and Madura I8,515,4I4 people, being an increase of about 170,000 over the previous year. The natives figure for $18,278,998$, of whom $8,921,348$ were males, while the remainder is made up of Europeans, Chinese, Arabs, and other foreign Orientals, the Celestials being, of course, in a large majority. This remark also applies to the other possessions in Netherlands India, including Sumatra, Celebes, \&c. Owing to the incompleteness of the returns of natives in these islands, no estimate of their total population can be arrived at.

\section{WILLIAM WILSON SAUNDERS}

WILLIAM WILSON SAUNDERS, F.R.S., F.L.S. \&c., who, as we stated last week, died on September I3, was born June 4, I809, the son of the Rev. James Saunders, Vicar of Kirtlington. He was educated at Addiscombe, and went to India as an engineer officer in the Hon. East India Company's service. While there he published his first scientific paper, in Gleanings in Science "Cn Hydraulic Cements," in I831, and also devoted a great part of his leisure to the study of plants and insects, and made collections, which he brought back with him in 1832 . Having left the service, he settled at Wandsworth, and shortly after joined his father-in-law in business at Lloyds, still continuing his natural history studies. He was one of the original members of the Entomological Society, and read his first paper, "On the Habits of some Indian Insects," in April, I834. "This was followed by many others, mostly of a descriptive nature. He was President of the Society in $184 \mathrm{I}, \mathrm{I} 856$, and 1857 , and many times served as vice-president. He was also elected a Fellow of the Linnean Society in 1833 , and was vice-president from 1856 to 1874 , and treasurer from 1861 to 1873 . He became a Fellow of the Royal Society in 1853, and was also a Fellow of the Zoological Society and Royal Horticultural Society, and on the Council of the latter he took an active part. His natural history collections gradually increased in extent from the time of his return from India, and he devoted himself principally while at Wandsworth to horticulture and entomology and to the formation of an extensive herbarium and collection of woods, with notes of the density and weight per cubic foot of each, which latter was exhibited at the great Exhibition of $185 \mathrm{I}$. The Report of the Juries for the Exhibition gives a classified catalogue of them, with remarks as to their uses, \&c.

In 1857 be went to reside at Hallfield, Reigate, and removed there his various collections, largely extending them, and adding collections of birds, shells, vegetable products, \&c. His attention, however, was always mainly given to horticulture and entomology, and especially to the study and cultivation of the aloes, Crassulaceæ, Cacti, and otber succulent plants which could not be duly studied in an herbarium, and to the smaller and more obscure species of orchids; and it was to bring these interesting and curious plants more prominently before the botanical world that he resolved on the publication of the "Refugium Botanicum," the first number of which appeared in April, I868. In this work he had the valuable assistance of Prof. H. G. Reichenbach for the descriptions of the orchids, and of Mr. J. G. Baker, of Kew, for the other families, the plates being chiefly from the drawings of the well-known botanical artist Mr. Fitch, although some were from drawings of his own. The Fungi also attracted a good deal of his attention, and he made a series of very accurate drawings of all he was able to obtain, some of which have been reproduced in the "Mycological Illustrations," edited by him with the assistance of Mr. Worthington G. Smyth and Mr. A. W. Bennett; the first part of this appeared in $187 \mathrm{I}$. Unfortunately neither the "Refugium" nor the "Mycological Illustrations" have ever been completed.

His entomological collection included insects of all orders, and though perhaps he gave more special attention to the Lepidoptera and Coleoptera, he was always 